\title{
Novel Techniques in Epilepsy Management: Venous Pacing and Capture of Electrical Activity in the Primate Cortex
}

Prakriti Gaba BS ${ }^{1}$, Christopher V DeSimone ${ }^{2}$, Benhur D Henz ${ }^{3}$, Paul A Friedman ${ }^{2}$, Charles J Bruce ${ }^{2}$, David R. Holmes ${ }^{2}$, Malini Madhavan², Krithika Vasudevan ${ }^{4}$, Douglas Wahnschaffe ${ }^{5}$, Steven Berhow ${ }^{5}$, Andrew J Danielsen ${ }^{6}$, Dorothy J Ladewig ${ }^{6}$, Susan B Mikell ${ }^{6}$, Susan B Johnson ${ }^{2}$, Scott H Suddendorf ${ }^{2}$, Tomas Kara ${ }^{2,7}$, Gregory A Worrell ${ }^{8}$, Samuel J Asirvatham ${ }^{2,9^{*}}$

${ }^{1}$ Mayo Medical School, Mayo Clinic, Rochester, MN, USA

${ }^{2}$ Division of Cardiovascular Disease, Department of Internal Medicine, Mayo Clinic, Rochester, MN, USA

IInstituto Brasília de Arritmia, Brasilia, Brazil

${ }^{4}$ University of Texas, Austin, USA

${ }^{5}$ Biomerics, Rogers, MN, USA

${ }^{6}$ Mayo Clinic Rochester, MN, USA

7ICRC - Department of Cardiovascular Diseases, St Anne's University Hospital, Brno, Czech Republic

${ }^{8}$ Division of Neurology, Department of Internal Medicine, Mayo Clinic, Rochester, MN, USA

${ }^{9}$ Department of Pediatrics and Adolescent Medicine Mayo Clinic, Rochester, MN, USA

\begin{abstract}
Objective: Pharmacotherapy for epilepsy is limited with $30 \%$ of patients' refractory to this approach of suppressing seizures. Current surgical options are invasive and carry significant morbidities including infection, bleeding, and the potential for deleterious neurocognitive effects. As a result, there is a burgeoning need for innovation to develop safer and efficacious interventions.

Methods: Four distinct catheters (2 existing: Cardima catheter, Standard EPT Blazer catheter; 2 new prototypes: balloon catheter, basket catheters) were tested in 12 baboons (21-30 kg, 100\% male). For each, we assessed whether or not the catheter was able to be maneuvered safely in various locations of the cerebral venous system, provide adequate cortical tissue contact to record signals, detect these signals as normal or abnormal, successfully stimulate the cortex, and capture the cortical tissue. Locations trialed included the petrosal sinus, straight sinus, vein of Galen, and occipital vein. Pacing cycle length and pacing thresholds varied among experiments.
\end{abstract}

Results: Successful mapping was conducted in all 12 baboons. The pacing cycle length varied from $75 \mathrm{~ms}$ to $650 \mathrm{~ms}$ depending on location of the cortex. Pacing threshold was recorded in $4 / 12$ (33\%) of the experiments; data is not available for the remaining 8/12 experiments. The threshold values ranged from $0.3-20 \mathrm{mAmps}$. Capture of cortical electrical activity was observed in $11 / 12(91.7 \%)$ experiments though the number of successful capture and stimulation attempts varied among experiments. The most reliable and consistent capture occurred with the use of our novel prototyped over-the-wire balloon catheter $(9 / 12 ; 75 \%)$ and basket catheter $(3 / 3 ; 100 \%)$. Necropsy and histology were performed post-experimentation, and only minimal complications were noted.

Conclusion: New electrode design can be maneuvered safely in the venous system, provide adequate cortical tissue contact to record signals, detect these signals as normal or abnormal, successfully stimulate the cortex, and capture cortical tissue. These novel devices merit further study in chronic baboons to establish long-term efficacy of continuous seizure recording.

Keywords: Epilepsy; Venous pacing; Primates; Cerebral cortex

\section{Introduction}

Epilepsy is a serious network disorder with variable presentation and subpar therapy [1]. Currently, 30\% of epilepsy patients remain refractory to medical therapy, especially those with mesial temporal lobe epilepsy [2]. Invasive techniques, including open resection, have been attempted; however, these can lead to unwanted side effects such as decline in neurocognitive function [2]. More recent neurostimulation techniques, including anterior thalamic deep brain stimulation and responsive neurostimulation at seizure foci, have been equivocal in their efficacy - mitigating seizure frequency by $40 \%$ immediately after surgery and in 50-69\% of patients after several years [3]. Apart from inconsistency, these stimulatory techniques lead too many complications, most of which are related to the implantation procedure and hardware, that is, electrode mistargeting, movementm and implantation site infection [3]. A combination of these factors has favored movement towards less invasive, non-surgical techniques for the treatment of epilepsy.

Vagal nerve stimulation has been used as a treatment of refractory epilepsy and has led to fewer procedural complications given minimally invasive placement in the neck as opposed to brain but has limited benefit for patients with bilateral interictal epileptiform activity and cortical malformations and may be subpar to anterior thalamic deep brain stimulation and responsive neurostimulation $[3,4]$. Previously, we have demonstrated successful navigation, mapping, and radiofrequency ablation of the cerebral cortex in porcine, canine, and baboon models through the venous sinuses and cerebral veins $[5,6]$. Here we explore the intra-venous

*Corresponding author: Samuel J Asirvatham, Mayo Clinic College of Medicine 200 First Street SW, Rochester, MN 55905, USA, Tel: 507-293-3376; Fax: 507255-2550; E-mail: asirvatham.samuel@mayo.edu

Received April 12, 2016; Accepted May 18, 2016 ; Published May 25, 2016

Citation: Prakriti Gaba BS, DeSimone CV, Henz BD, Friedman PA, Bruce CJ et al. (2016) Novel Techniques in Epilepsy Management: Venous Pacing and Capture of Electrical Activity in the Primate Cortex. J Neurol Neurophysiol 7: 373. doi:10.4172/2155-9562.1000373

Copyright: ㄷ 2016 Prakriti Gaba BS, et al. This is an open-access article distributed under the terms of the Creative Commons Attribution License, which permits unrestricted use, distribution, and reproduction in any medium, provided the original author and source are credited. 
Citation: Prakriti Gaba BS, DeSimone CV, Henz BD, Friedman PA, Bruce CJ, et al. (2016) Novel Techniques in Epilepsy Management: Venous Pacing and Capture of Electrical Activity in the Primate Cortex. J Neurol Neurophysiol 7: 373. doi:10.4172/2155-9562.1000373

Page 2 of 7

manipulation of novel pacing electrodes. We hope to understand whether these electrodes can provide a safer means to detect cortical signals, determine whether they are normal or abnormal, stimulate the cortex, and capture the cortical tissue since doing so would have significant implications for future epilepsy therapy.

\section{Methods}

\section{Animal preparation}

This study was approved by the Mayo Clinic Institutional Animal Care and Use Committee (IACUC). Twelve baboons (21-30 kg, 100\% male) were tested under general anesthesia consisting of $1-3 \%$ of isoflurane and sodium pentothal. Intravenous heparin was injected periodically to maintain a therapeutic activated clotting time of 250 seconds.

\section{Venous Access and Electrical Mapping}

In order to access the animal venous vasculature prior to pacing a multipurpose 4-French catheter was inserted into either the internal jugular vein or femoral vein. Venograms were obtained at various locations, including the petrosal sinus, straight sinus, vein of Galen, and occipital vein (Table 1). For mapping and subsequent ablation, additional catheters were inserted into the internal carotid artery as described previously [5]. Seizures were induced by either electrical stimulation/pacing or injection of penicillin in venous vessels as described previously [5]. Mapping of electrical activity was performed at high $(200 \mathrm{~Hz})$ and low $(50-200 \mathrm{~Hz})$ frequencies [5].

\section{Pacing}

Pacing was conducted using two existing catheters (2.7-Fr

\begin{tabular}{|c|c|c|c|c|c|c|c|c|c|}
\hline Experiment & $\begin{array}{c}\text { Animal } \\
\text { Type }\end{array}$ & $\begin{array}{l}\text { Catheter used to } \\
\text { obtain venograms }\end{array}$ & $\begin{array}{l}\text { Location of venous } \\
\text { stimulation and/or cortical } \\
\text { structure stimulated }\end{array}$ & Catheter used for Pacing & $\begin{array}{l}\text { Pacing cycle } \\
\text { length (ms) }\end{array}$ & $\begin{array}{l}\text { Threshold } \\
\text { (ma) }\end{array}$ & $\begin{array}{l}\text { Capture } \\
\text { Obtained? }\end{array}$ & Complications & $\begin{array}{l}\text { Length of } \\
\text { Experiment } \\
\quad(\mathrm{min})\end{array}$ \\
\hline 1 & Baboon & $\begin{array}{l}\text { 6-French } \\
\text { multipurpose } \\
\text { catheter }\end{array}$ & $\begin{array}{l}\text { Petrosal Sinus, Vein of } \\
\text { Galen }\end{array}$ & $\begin{array}{l}\text { Cardima } 2.7-\text { French decapolar } \\
\text { catheter; } 6 \text {-French } 4 \mathrm{~mm} \text { tipped } \\
\text { EPT catheter; our prototyped } \\
\text { over-the-wire balloon catheter }\end{array}$ & $80-600$ & - & Yes & No & 257 \\
\hline 2 & Baboon & $\begin{array}{l}\text { 6-French 4-mm } \\
\text { tipped EPT } \\
\text { catheter }\end{array}$ & $\begin{array}{l}\text { the occipital lobe, right } \\
\text { mesial temporal lobe, } \\
\text { petrosal sinus and the vein } \\
\text { of Labbe }\end{array}$ & $\begin{array}{l}\text { Cardima } 2.7 \text {-French decapolar } \\
\text { catheter; } 6 \text {-French } 4 \mathrm{~mm} \text { tipped } \\
\text { EPT catheter; our prototyped } \\
\text { over-the-wire balloon catheter }\end{array}$ & $75-300$ & - & No & No & 160 \\
\hline 3 & Baboon & $\begin{array}{c}\text { Cardima } \\
\text { 2.7-French } \\
\text { decapolar catheter; } \\
\text { 6-French } 4 \mathrm{~mm} \\
\text { tipped EPT } \\
\text { catheter }\end{array}$ & petrosal sinus & $\begin{array}{l}\text { Cardima } 2.7-\text {-French decapolar } \\
\text { catheter; our prototyped over- } \\
\text { the-wire balloon catheter }\end{array}$ & $500-650$ & 11 & $\begin{array}{l}\text { Yes (with our } \\
\text { prototyped over- } \\
\text { the-wire balloon } \\
\text { catheter only) }\end{array}$ & No & 174 \\
\hline 4 & Baboon & $\begin{array}{l}\text { 6-French 4-mm } \\
\text { tipped EPT } \\
\text { catheter; our } \\
\text { prototyped over- } \\
\text { the-wire balloon } \\
\text { catheter }\end{array}$ & $\begin{array}{l}\text { Vein of Galen, mid brain, } \\
\text { occipital lobe ( } 2 \text { sites) }\end{array}$ & $\begin{array}{l}\text { 6-French 4-mm tipped EPT } \\
\text { catheter; our prototyped over- } \\
\text { the-wire balloon catheter }\end{array}$ & 75 & $0.3-20$ & $\begin{array}{l}\text { Yes (with our } \\
\text { prototyped over- } \\
\text { the-wire balloon } \\
\text { catheter only) }\end{array}$ & $\begin{array}{l}\text { Yes (coagulum } \\
\text { formation, } \\
\text { electrode } \\
\text { breakage) }\end{array}$ & 164 \\
\hline 5 & Baboon & $\begin{array}{l}\text { our prototyped } \\
\text { over-the-wire } \\
\text { balloon catheter }\end{array}$ & $\begin{array}{l}\text { Occipital lobe ( } 4 \text { sites), } \\
\text { temporal lobe, sagittal sinus }\end{array}$ & $\begin{array}{l}\text { our prototyped over-the-wire } \\
\text { balloon catheter }\end{array}$ & 75 & 0.7 & Yes & No & 171 \\
\hline 6 & Baboon & $\begin{array}{l}\text { 6-French 4-mm } \\
\text { tipped EPT } \\
\text { catheter; our } \\
\text { prototyped over- } \\
\text { the-wire balloon } \\
\text { catheter; Basket } \\
\text { catheter }\end{array}$ & $\begin{array}{l}\text { Base of brain, petrosal sinus, } \\
\text { straight sinus; subdural } \\
\text { sinus, temporal lobe (for } \\
\text { basket catheter) }\end{array}$ & $\begin{array}{c}\text { 6-French 4-mm tipped EPT } \\
\text { catheter; our prototyped over- } \\
\text { the-wire balloon catheter; Basket } \\
\text { catheter }\end{array}$ & 75 & - & Yes & No & 345 \\
\hline 7 & Baboon & $\begin{array}{l}\text { prototyped over- } \\
\text { the-wire balloon } \\
\text { catheter; Basket } \\
\text { catheter }\end{array}$ & $\begin{array}{l}\text { Petrosal sinus, straight } \\
\text { sinus; artery (for basket } \\
\text { catheter) }\end{array}$ & $\begin{array}{l}\text { prototyped over-the-wire balloon } \\
\text { catheter; Basket catheter }\end{array}$ & 75 & 10 & Yes & No & 234 \\
\hline 8 & Baboon & $\begin{array}{l}\text { prototyped over- } \\
\text { the-wire balloon } \\
\text { catheter; Basket } \\
\text { catheter }\end{array}$ & $\begin{array}{l}\text { Occipital lobe, basilar vein } \\
\text { (basket catheter) }\end{array}$ & $\begin{array}{l}\text { prototyped over-the-wire balloon } \\
\text { catheter }\end{array}$ & 75 & - & Yes & $\begin{array}{l}\text { Yes (breakage } \\
\text { of balloon } \\
\text { catheter) }\end{array}$ & 203 \\
\hline 9 & Baboon & $\begin{array}{l}\text { prototyped over- } \\
\text { the-wire balloon } \\
\text { catheter }\end{array}$ & $\begin{array}{l}\text { Occipital lobe, straight sinus, } \\
\text { straight sinus, temporal } \\
\text { fissure }\end{array}$ & $\begin{array}{l}\text { prototyped over-the-wire balloon } \\
\text { catheter }\end{array}$ & 75 & - & Yes & No & 334 \\
\hline 10 & Baboon & $\begin{array}{l}\text { prototyped over- } \\
\text { the-wire balloon } \\
\text { catheter }\end{array}$ & $\begin{array}{l}\text { Straight sinus, occipital lobe; } \\
\text { sigmoid sinus }\end{array}$ & $\begin{array}{l}\text { prototyped over-the-wire balloon } \\
\text { catheter }\end{array}$ & 75 & - & Yes & No & 262 \\
\hline 11 & Baboon & $\begin{array}{c}\text { Cardima } \\
2.7-\text { French } \\
\text { decapolar catheter; } \\
\text { prototyped over- } \\
\text { the-wire balloon } \\
\text { catheter }\end{array}$ & Left vein base & $\begin{array}{l}\text { Cardima } 2.7-\text { French decapolar } \\
\text { catheter; prototyped over-the- } \\
\text { wire balloon catheter }\end{array}$ & 75 & - & $\begin{array}{l}\text { Yes (with } \\
\text { Cardima } \\
\text { 2.7-French } \\
\text { decapolar } \\
\text { catheter only) }\end{array}$ & No & 374 \\
\hline 12 & Baboon & $\begin{array}{c}\text { Cardima } \\
\text { 2.7-French } \\
\text { decapolar catheter; } \\
\text { 6-French } 4 \mathrm{~mm} \\
\text { tipped EPT } \\
\text { catheter }\end{array}$ & Occipital lobe, parietal lobe & $\begin{array}{l}\text { prototyped over-the-wire balloon } \\
\text { catheter; basket catheter }\end{array}$ & 75 & - & $\begin{array}{l}\text { Yes (with basket } \\
\text { catheter only) }\end{array}$ & No & 300 \\
\hline
\end{tabular}

Table 1: Summary of results. Types of catheters, location of pacing, catheter type used, number of unique sites paced, cycle length, threshold, and whether or not capture was achieved at the respective sites. 
Citation: Prakriti Gaba BS, DeSimone CV, Henz BD, Friedman PA, Bruce CJ, et al. (2016) Novel Techniques in Epilepsy Management: Venous Pacing and Capture of Electrical Activity in the Primate Cortex. J Neurol Neurophysiol 7: 373. doi:10.4172/2155-9562.1000373

octapolar microelectrode catheter [Revelation Cardima ${ }^{\mathrm{Tw}}$, Fremont CA] \& 6-Fr 4-mm tip, deflectable EPT catheter [Blazer Boston Scientific ${ }^{\text {tw }}$, Natick, MA]), and two novel minimally invasive pacing catheters (over-the-wire balloon (Figure 1) and basket (Figure 2) catheters). The over-the-wire balloon catheter is lined with polytetrafluoroethylene (PTFE), braided with stainless steel allowing it to be safely manuveured intravascularly, and contains a Pebax outer jacket and consists of six electrodes. There are two rows of electrodes consisting of three electrodes each. Each row of electrodes is $5 \mathrm{~mm}$ apart from the other and each electrode is $2 \mathrm{~mm}$ apart from the next within the same row allowing for pacing from several different locations without altering catheter position. A detailed schematic of the over-the-wire balloon catheter is shown in Figure 1 [5]. In contrast, the novel basket catheter, composed of Nitinol, consists of eight 1 $\mathrm{mm}$ long, 90\% Platinum/10\% Iridium electrodes. The electrodes are insulated from Nitinol with Polyimide and are spaced $1.9 \mathrm{~mm}$ along the axis and $1.875 \mathrm{~mm}$ radially, and the device is designed such that it remains securely in place intravascularly to allow continuous pacing if required. A detailed schematic is shown in Figure 2.

Each electrode was evaluated in various cerebral locations (the mesial temporal lobe and occipital lobe) for its ability to safely be manipulated through the venous system, provide adequate cortical tissue contact to record signals, detect these signals as normal or abnormal, stimulate the cortex, and capture the cortical tissue (Table 1). Several frequencies were attempted ranging from 30-600
$\mathrm{Hz}$, and various cycle lengths of pacing were implemented. These cycle lengths were adjusted with each stimulation or until electrical capture was obtained. Electrograms before and after stimulation were recorded from the electrodes on each respective intravenous pacing catheter and were documented for normal vs. abnormal activity using a multichannel recording device (Prucka ${ }^{\mathrm{n} w}$, General Electric, Milwaukee, USA) with filter settings ranging from 0.5$500 \mathrm{~Hz}$. Stimulation was confirmed by electrogram comparison pre and post pacing shown in Figures 3-5 as well as by the movement of the animal. Capture was characterized by a disruption of normal brain activity and was recorded for each experiment in which it occurred.

\section{Navigation with magnetic technology}

In order to efficiently maneuver the various catheters through the labyrinthine venous sinuses, the NIOBE II system (Stereotaxis, SaintLouis, MO, USA) was utilized [7]. This technology generates a magnetic field which allows for remote control of a steel-tipped, 1.1 Fr-catheter through human vascular structures.

\section{Necropsy}

Post-experimentation, animals were euthanized by inducing ventricular fibrillation through direct current applied to the cardiac ventricle. Necropsy was conducted to examine the brain for any grossly abnormal findings from pacing and ablation.

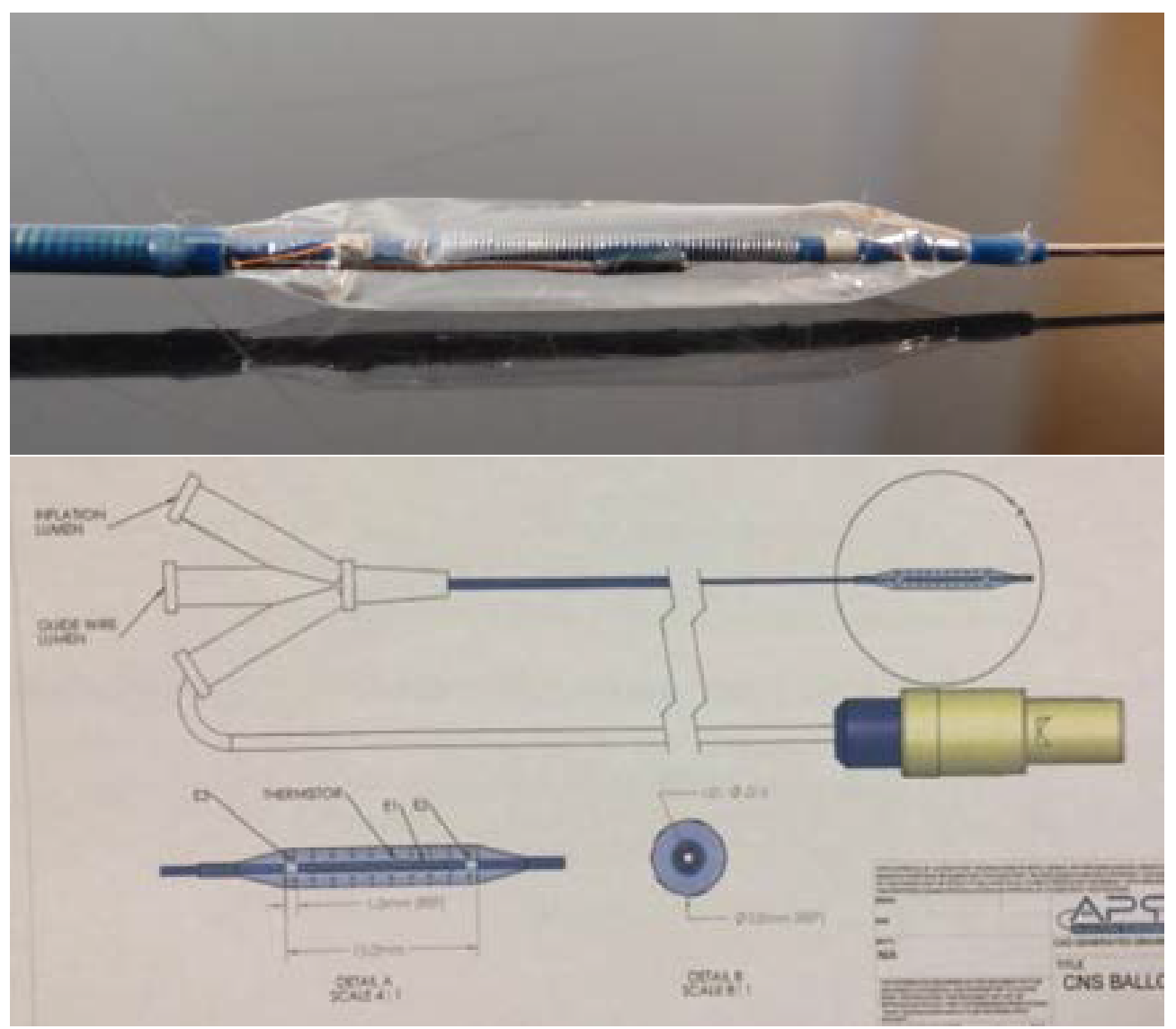

Figure 1: Over-the-wire balloon catheter for venous pacing in the CNS. (Left: Depicted in this image is the novel over-the-wire balloon catheter, which is lined with polytetrafluoroethylene (PTFE), braided with stainless steel and containing a Pebax outer jacket, consists of 6 electrodes. It consists of 2 rows consisting of 3 electrodes each. Each row of electrodes is $5 \mathrm{~mm}$ apart from the other and each electrode is $2 \mathrm{~mm}$ apart from the next within the same row, allowing for pacing from several different locations without altering catheter position. Right: Detailed schematic of over-the-wire balloon catheter). 
Citation: Prakriti Gaba BS, DeSimone CV, Henz BD, Friedman PA, Bruce CJ, et al. (2016) Novel Techniques in Epilepsy Management: Venous Pacing and Capture of Electrical Activity in the Primate Cortex. J Neurol Neurophysiol 7: 373. doi:10.4172/2155-9562.1000373

Page 4 of 7

Figure 2: Novel Basket Catheter for venous pacing in the CNS. (Left: Depicted in this image is the novel Basket catheter used for pacing. It is made up of Nitinol and consists of $90 \%$ Platinum $10 \%$ Iridium electrodes. The electrodes are insulated from Nitinol with Polyimide. Right: Detailed schematic of basket catheter).
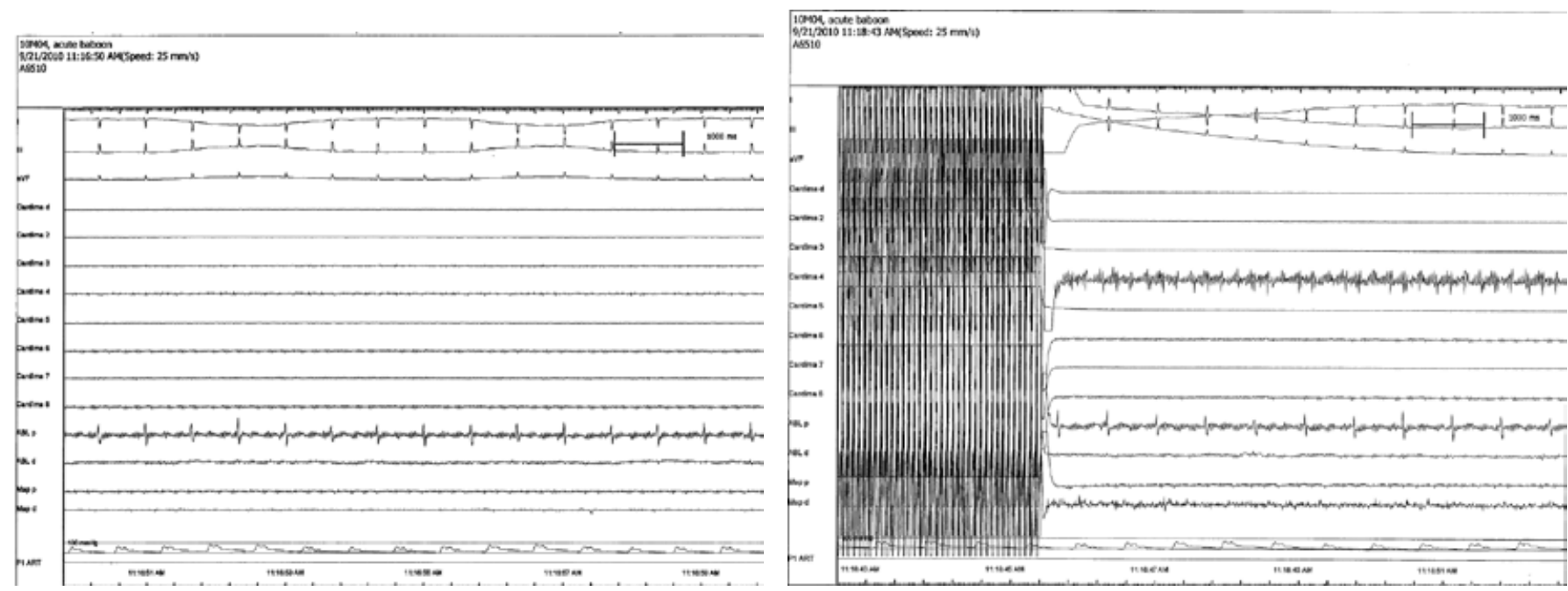

Figure 3: Pre- and post-capture of cortical tissue after high rate pacing with Cardima 2.7-Fr catheter. (Left: Recording of electrical activity from Cardima 2.7-Fr catheter placed left vein base at a frequency of $30 \mathrm{~Hz}$. Right: Pacing-induced capture of cerebral activity).

\section{Results}

We recorded electrical signals in all tissues tested. We were able to stimulate cortical tissue in a majority of cortical sites and noted capture of cortical tissue when the intravenous catheters were overlying occipital lobe and temporal lobe specifically (Table 1).

Individualized by catheter type, the 2.7-Fr Cardima catheter was tried in four separate experiments. Capture was obtained on 2/4 (50\%) occasions, and cycle lengths varied among experiments from 75-650 ms. The 6-Fr 4-mm tip, deflectable EPT catheter was tried in four separate experiments. Capture was obtained on $2 / 4(50 \%)$ occasions, and cycle lengths varied among experiments from 75-600 ms. The over-the-wire balloon catheter was tried in 12 separate experiments (Figure 1). Capture was obtained on 9/12 (75\%) occasions, and cycle lengths varied among experiments from 75-650 ms. Lastly, the basket catheter was tried in three separate experiments (Figure 2). Capture was obtained on $3 / 3(100 \%)$ occasions. All experiments were conducted with cycle length of $75 \mathrm{~ms}$. 

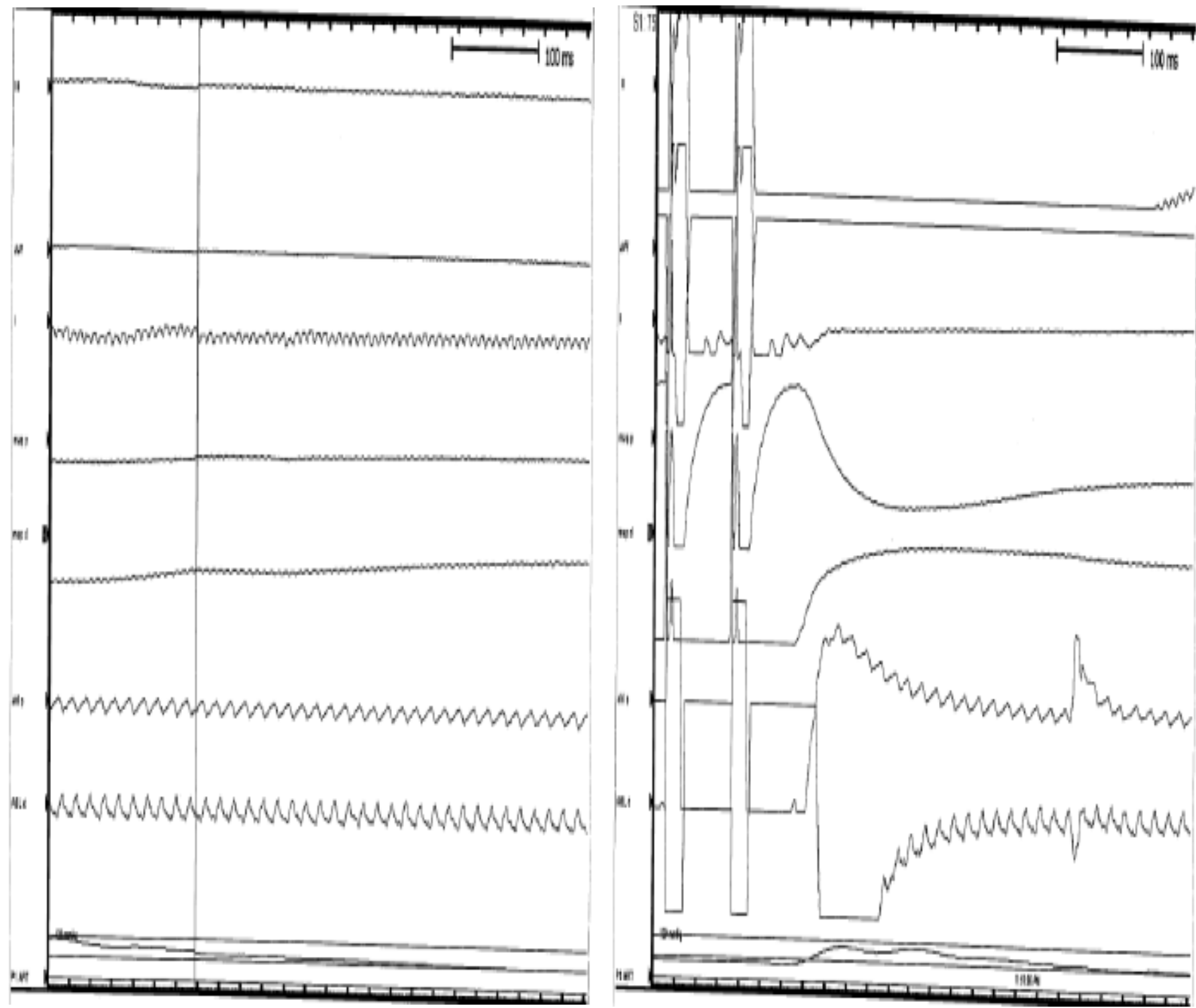

Figure 4: Pre- and post-capture of cortical tissue after high rate pacing with over-the-wire balloon catheter. (Left: Recording of electrical activity from over-the-wire balloon catheter placed straight sinus at a frequency of $60 \mathrm{~Hz}$. Right: Pacing-induced capture of cerebral activity).

Overall, procedures lasted for 248 [160-374] min, and cycle length during the experiments ranged from $75 \mathrm{~ms}$ to $650 \mathrm{~ms}$. Threshold was recorded in 4/12 (33\%) experiments; data not recorded for the others. Threshold values ranged from 0.3-20 mAmps. Capture of cortical electrical activity was seen in stimulations performed in 11/12 (91.7 \%) animal models, the majority of which occurred with use of our novel prototypical over-the-wire balloon catheter (Figure 1). Examples of capture obtained pre- and post-pacing using this catheter are shown in Figure 4 while those obtained by the 2.7-Fr Cardima catheter as well as the basket catheter are depicted in Figures 3 and 5, respectively.

\section{Pathology and Complications}

Complications from the procedure were rare. Two of 12 (17\%) studies resulted in complications, including coagulum formation on catheter and catheter breakage (of over-the-wire-balloon catheter during maneuvering into the right distal sigmoid sinus) (Table 1). The catheter breakage was likely related to the specific catheter used. Further iterations of the catheter did not result in breakage due to improved manufacturing. None of the animal brain specimens examined grossly and histologically showed signs of hemorrhage, arterial infarction or venous thombosis. Furthermore, no other gross abnormalities were noted.

\section{Discussion}

Our new intravenous catheters are able to detect, stimulate, and capture cerebral electrical activity. Of the four minimally invasive intravenous catheter-based devices tested in our series of experiments, our novel balloon catheter and basket catheter prototypes were the most successful in achieving consistent capture. In fact, in experiments 1,3 , and 4, only our prototyped over-the-wire balloon catheter (Figure 1) was able to obtain capture, while the Cardima 2.7-French decapolar catheter and the 6-French $4 \mathrm{~mm}$ tipped EPT catheter failed to capture cortical activity. The basket catheter (Figure 2) was only tried in three experiments, yet showed successful capture in all three. The 6-Fr 4 

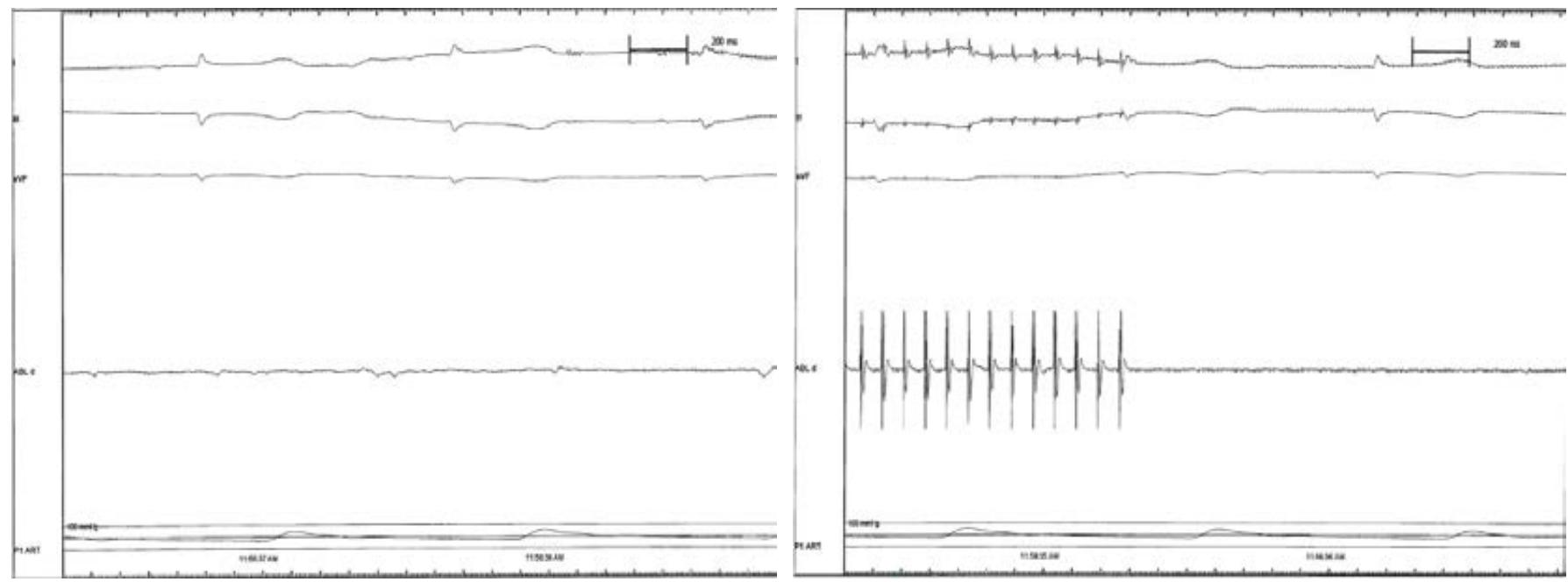

Figure 5: Pre- and post-capture of cortical tissue after high rate pacing with basket catheter. (Left: Recording of electrical activity from basket catheter placed in artery at a frequency of $30 \mathrm{~Hz}$. Right: Pacing-induced capture of cerebral activity using basket catheter).

mm-tipped EPT catheter was, on numerous occasions, limited in maneuverability, particularly past the petrosal sinus.

In experiment 2, no capture was obtained from either catheter. Possible explanations may be a result of inadequate placement of the catheters in the respective venous drainage sites, preventing solid contact with tissue and resulting in lack of capture. From experiment 4 onwards, we did not use a Cardima 2.7-Fr decapolar catheter (except for once more in experiment 11) since it was felt that we had enough data in terms of mapping using this catheter, and we wanted to focus efforts on testing the newer prototypes. 6-Fr $4 \mathrm{~mm}$-tipped EPT catheter and first-time use of our prototyped over-the-wire balloon catheter were prioritized in these later experiments for pacing.

Current treatment for epilepsy remains subpar. The ability to detect and stimulate cortical tissue intravenously as well as capture these electrical signals may offer a unique manner with which to find epileptic foci. This, coupled with intravenous ablation, which we have described in prior studies, may offer a unique, less invasive, and safer alternative to current options for epilepsy treatment. ${ }^{6,7}$ Additional studies assessing success of these devices in chronic animal studies and human trials are needed to understand long-term efficacy.

\section{Limitations}

There are several limitations to this study. First, our studies are proof-of-concept studies that were performed in the acute setting. Thus, it is unclear as to what the chronic results of implantation of the novel devices will be. Further experiments in animal models will be needed to confirm efficacy. Moreover, all experiments were conducted in animal models. To determine the efficacy in patients, human trials will be crucial if long-term outcomes of this novel device in animal models are successful. Additionally, all of the above studies were conducted with the animals sedated under general anesthesia, which is known to cause lower frequency and higher amplitude of signals on EEG [8]. It is therefore possible that these drugs may have had an impact on the capture signals we recorded. While removing such a confounder may not be possible, it is a limitation we must consider.

Lastly, 1 of the 12 experiments (experiment \#4) did lead to a complication of coagulum formation on the device. In future studies, we plan to not only have irrigation ability added to the device to preclude this but also apply a negative charge to the electrodes to prevent coagulum formation $[9,10]$. Drug-coated balloon therapy may also be implemented on the catheters to prevent stenosis of devices intravascularly [11]. Coupled with anticoagulation therapy, these modifications will minimize the risk of complications in patients implanted.

\section{Conclusion}

Of the four catheters tested at the variety of venous sites (including the straight sinus, vein of Galen, etc.) in the cerebral cortex, the novel over-the-wire venous balloon catheter most consistently detected cerebral electrical activity. Stimulation with this device results in local cerebral capture and holds promise for the future development of chronic deep brain and cortical stimulatory devices for the management of epilepsy. Further chronic animal studies and human trials are needed to evaluate such chronic efficacy.

\section{Acknowledgement}

C.V.D. was partially supported by an NIH T32 training grant (HL 007111). This project was funded by the Discovery Translational Fund and the University of MN Partnership grant.

\section{References}

1. Liao W, Ji GJ, Xu Q, Wei W, Wang J, et al. (2016) Functional Connectome before and following Temporal Lobectomy in Mesial Temporal Lobe Epilepsy. Sci Rep 6: 23153.

2. Gross RE, Mahmoudi B, Riley JP (2015) Less is more: novel less-invasive surgical techniques for mesial temporal lobe epilepsy that minimize cognitive impairment. Curr Opin Neurol 28: 182-191.

3. Fisher RS, Velasco AL (2014) Electrical brain stimulation for epilepsy. Nat Rev Neurol 10: 261-270.

4. Connor DE, Nixon M, Nanda A, Guthikonda B (2012) Vagal nerve stimulation for the treatment of medically refractory epilepsy: a review of the current literature. Neurosurg Focus 32: E12.

5. Henz BD, Friedman PA, Bruce CJ, Holmes DR, Bower M, et al. (2014) Advances in radiofrequency ablation of the cerebral cortex in primates using the venous system: Improvements for treating epilepsy with catheter ablation technology. Epilepsy Res 108: 1026-1031.

6. Henz BD, Friedman PA, Bruce CJ, Holmes DR, Okumura Y, et al. (2008) Successful radiofrequency ablation of the cerebral cortex in pigs using the 
Citation: Prakriti Gaba BS, DeSimone CV, Henz BD, Friedman PA, Bruce CJ, et al. (2016) Novel Techniques in Epilepsy Management: Venous Pacing and Capture of Electrical Activity in the Primate Cortex. J Neurol Neurophysiol 7: 373. doi:10.4172/2155-9562.1000373

Page 7 of 7

venous system: possible implications for treating CNS disorders. Epilepsy Res 80: $213-218$

7. Kara T, Leinveber P, Vlasin M, Jurak P, Novak M, et al. (2014) Endovascular brain intervention and mapping in a dog experimental model using magneticallyguided micro-catheter technology. Biomed Pap Med Fac Univ Palacky Olomouc Czech Repub 158: 221-226.

8. Brown EN, Lydic R, Schiff ND (2010) General anesthesia, sleep, and coma. N Engl J Med 363: 2638-2650.

9. Lim B, Venkatachalam KL, Henz BD, Johnson SB, Jahangir A, et al. (2016)
Prevention of coagulum formation with simultaneous charge delivery in radiofrequency ablation: A Canine Model. JACC: Clinical Electrophysiology 2 233-241.

10. Lim B, Venkatachalam KL, Jahangir A, Johnson SB, Asirvatham SJ (2008) Concurrent application of charge using a novel circuit prevents heatrelated coagulum formation during radiofrequency ablation. J Cardiovasc Electrophysiol 19: 843-850.

11. De SC, Holmes DR, Ebrille E, Syed FF, Ladewig DJ, et al. (2015) Direct pulmonary vein ablation with stenosis prevention therapy. J Cardiovasc Electrophysiol. 